\title{
ISLAMIC HERITAGE ARCHITECTURE ANALYSIS AND RESTORATION OF RAS CHERRATINE IN FEZ, MOROCCO
}

\author{
K. EL HARROUNI ${ }^{1} \&$ A. EL HAMMOUMI ${ }^{2}$ \\ ${ }^{1}$ Ecole Nationale d'Architecture, Morocco. \\ ${ }^{2}$ Faculté des Sciences de Rabat, Université Mohamed V, Morocco.
}

\begin{abstract}
Er-Rachidia or Ras Cherratine Madrasa, a listed Islamic heritage building in Fez Medina built by Sultan Moulay Rachid in 1670, was the residence and school for students who attended the nearby Al Quaraouiyine University, which is one of the oldest universities in the Islamic world. The Madrasa was restored in 2008 by the $\mathrm{Al}$ Omrane Group and other local authorities. This article introduces the treatment programme provided for restoration of the vertical and horizontal structures. It also presents the main results of activities carried out in Ras Cherratine Madrasa in the context of the collaborative project NIKER (new integrated knowledge-based approaches to the protection of cultural heritage from earthquakeinduced risk). These activities include visual inspection of the main damage and problems requiring intervention, mechanical tests for material and wall element characterization, the seismic performance of the masonry building derived from ambient vibration tests, seismic vulnerability analysis and structural modelling of the heritage building. The article concludes by emphasizing that this rich Islamic heritage architecture is vulnerable and then gives some objectives and justification of the need for intervention.

Keywords: ambient vibration tests, Islamic heritage architecture, restoration, seismic vulnerability, structural modelling.
\end{abstract}

\section{INTRODUCTION}

Most of the historic buildings and monuments and Islamic heritage architecture are located in the active seismic zones, which accelerate their vulnerability. These constructions should be preserved over time, especially against earthquakes that nowadays constitute one of the most devastating phenomena. Earthquakes are a complex societal problem, because they have a low annual probability of occurrence, but high probability of causing significant damage to the structures.

Fez Medina, a spiritual and cultural city founded in 789 , has been affected by some violent seisms. The frequency of the earthquakes that struck the town of Fez seems quite interesting in the chronology of the major earthquakes in Morocco (in the years 1046, 1079, 1408, 1522, $1623,1624,1708,1719,1755,1773,1776,1867,1929$, 1969). The Fez geographic location on a fertile plain, in the hollow of a valley, made it an economic, political and strategic crossroad, and was a decisive factor in the city's development and influence. The medina is characterized by the subtle sumptuousness of its palaces, the richness of its museums, the solemn grandeur of its Madrasas and the magnificent profusion of its mosques. The Al Quaraouiyine University mosque was built in 857 and marked the start of the city's golden age. This university is considered to be one of the oldest universities in the Islamic world.

The Madrasas (Koranic universities or Islamic educational institutions) bear living witness to the city's intellectual and scientific past. They are the work of the Marinid sultans,

This paper is part of the Proceedings of the International Conference on Islamic Heritage Architecture and Art (Islamic Heritage Architecture 2016)

www.witconferences.com
} 
and played a prominent part in political, educational and cultural life. Founded in the 13th century, the first to be built was the Seffarine Madrasa; the Al-Attarine Madrasa was built in 1325 and is one of the wonders of the city; the Ras Cherratine Madrasa was built by Sultan Moulay Rachid in the 17th century and could accommodate up to 200 students at a time.

The Ras Cherratine Madrasa, a national monument, is the largest Madrasa in Fez and was a residence and study space for students who attended the nearby Al Quaraouiyine University. The Madrasa not only represents one of the architectural characteristics of Fez but also reflects the interest accorded to the students and the Sufi movement in the imperial city. It has been restored by the Holding company Al Omrane [1], under the agreement between the Ministry of Culture and the Ministry in charge of Housing and Urbanism. Al Omrane has given a new life to this prestigious institution, which has become a nice space for exhibition and education in the fields of heritage and architecture. This article presents briefly the treatment programme provided for restoration of vertical and horizontal structures, architectural elements and decorations.

Section 2 presents the main results of activities carried out in Ras Cherratine Madrasa, selected as one of the case studies of the FP7 collaborative project: NIKER (new integrated $k$ nowledge-based approaches to the protection of cultural heritage from $e$ arthquake-induced risk) [2]. These activities include mechanical tests of construction materials (fired clay bricks, lime mortar, cedar wood) and wall element characterization, the evaluation of seismic vulnerability of the building, structural modelling and dynamic monitoring for the characterization of the dynamic response of the building.

\section{HISTORICAL DESCRIPTION AND PREVIOUS INTERVENTION ACTIONS}

The Madrasa has undergone a series of repairs and restorations during its life cycle, especially during the period 1961-1978. The consolidation works in 1965 were the most important (El Alaoui [3]): (1) the demolition of parts of the wall overlooking the patio and also the roof of the prayer hall which leaned dangerously and was at risk of collapse and destruction of the wooden frame; (2) reconstruction of the wall; (3) consolidation of the wooden roof supported on a reinforced concrete chaining and columns.
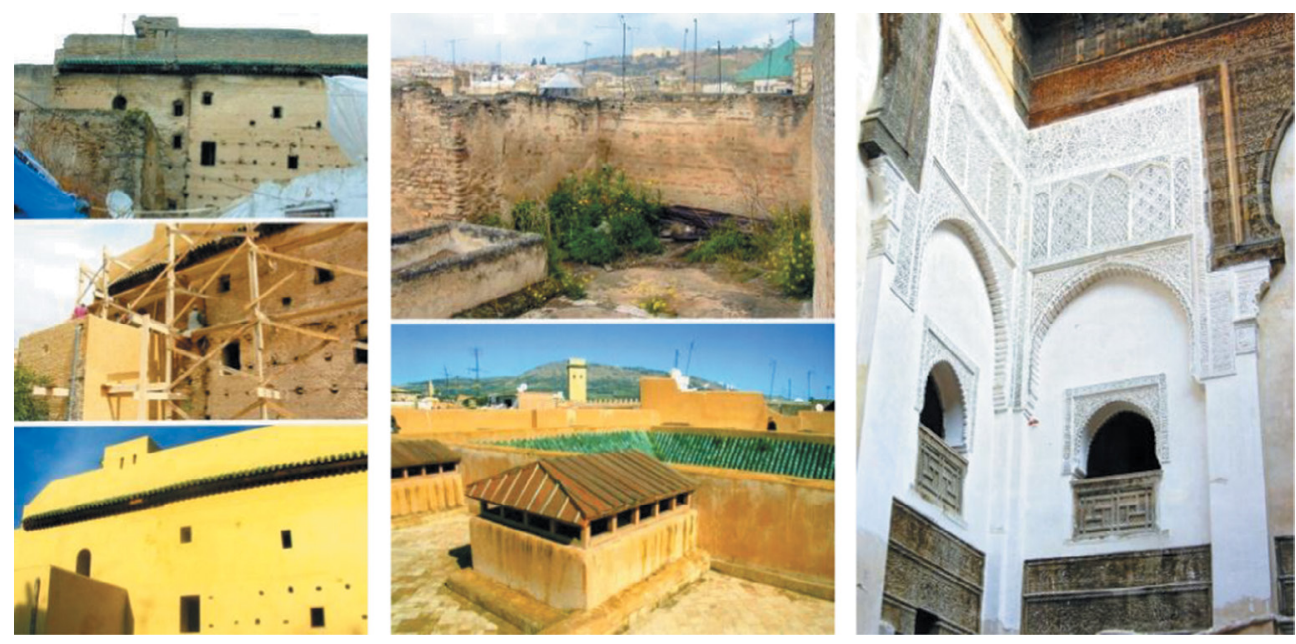

Figure 1: Treatment of the exterior façade, the terrace and the courtyard interior façade (Groupe Al Omrane [1]). 
During the period 2006-2008, the Ras Cherratine Madrasa was restored by the Al Omrane Group, a national company under the Ministry of Housing and Urbanism, responsible for the implementation of state policy in social housing and town planning sectors. The project led by the Al Omrane Group was the subject of extensive consultations with representatives of the Ministry of Culture, Ministry of Endowments and Islamic Affairs, Ministry of Tourism, local authorities and other administrative services including the Agency for the Dedensification and Rehabilitation of Fez Madina (ADER), the Urban Agency and Safeguard of Fez. The intervention programme consisted of restoring the entire Madrasa in accordance with the universal principles of historic building restoration and conservation. The restoration programme was concerned with vertical and horizontal structures, architectural elements and decorations, use of the same original materials including fired clay bricks, earth, lime mortar, wood, plaster, zellij, etc, and the same traditional construction techniques (Fig. 1).

\section{PRESENT CONDITIONS, INSPECTION, ANALYSIS AND INTERVENTION}

\subsection{Need for intervention and justification}

The recent analyses and test campaigns carried out within the NIKER project have shown that the seismic capacity of the structure of Ras Cherratine Madrasa should be improved. There are several reasons calling for a possible intervention:

(1) The building shows damage in different structural elements such as cracking at some wall locations, which may influence negatively the seismic performance.

(2) In spite of being located in a moderate seismic region (acceleration for Fez region: $10 \% \mathrm{~g}$ ), the building might be in risk because of its audacious structural features, involving wooden roof above the dome. The structure of the building may collapse, mainly the terrace floor. The seismic capacity of the building is actually limited (as shown in the structural analyses) by such singular structural features. The seismic analyses carried out on a global model have highlighted some of the weak points of the structure, in particular, the walls and the wall-wall and wall-floor connections. The results of the seismic analysis are briefly presented.

\subsection{Visual inspection: Main damage and problems requiring intervention}

The building is actually damaged, which may require intervention and alterations. The main alterations are as follows:

- Cracks: There are very large cracks in the walls around the dome and there is a problem of separation of joints. A visible deterioration can also be seen on the exterior walls, outside the Madrasa; these walls are reinforced with horizontal wooden planks (Fig. 2).

- Deformation: The wooden roof above the dome is supported on a reinforced concrete chaining laid on poorly executed concrete columns, dating from 1965. The wooden structure shows a perceptible deformed condition (Fig. 3).

- Loss of mortar or too much mortar: This problem related to too much mortar compared with fired bricks in walls could yield a resistance to compression and shear.

- Structural connections: There are some horizontal connecting elements between the Madrasa and the surrounding buildings using wooden beams and arches, which present some of the weak points of the structure. The type of connection between the wooden beams and fired clay brick walls can be considered as semi-rigid for structural modelling. 


\subsection{Geometric survey and research materials}

The Ras Cherratine Madrasa structure has three levels and the common materials of masonry construction are fired bricks. The thickness of the front walls ranges from 60 to $80 \mathrm{~cm}$, while that of the inner wall is $40 \mathrm{~cm}$. The ground floor is $4.8 \mathrm{~m}$ high, while the first and second floors are $3 \mathrm{~m}$ high. The overall building height is about $12 \mathrm{~m}$. The floor diaphragms are made of wooden beams and the type of wood commonly used is cedar. The geometry is described in the structural plans (Figs. 4 and 5).

\subsubsection{Wall material}

Mechanical tests have been carried out to characterize both the materials' behaviour (specimen of fired clay bricks, mortar made from a mixture of two-thirds clay and one-third wellhomogenized lime) and masonry wall prototype (Table 1).

\subsubsection{Floor material: Cedar wood}

The Madrasa floor is made from cedar beams with the following characteristics from the experimental tests: specific weight $\left(0.450 \mathrm{~g} / \mathrm{cm}^{3}\right)$ and longitudinal modulus of elasticity
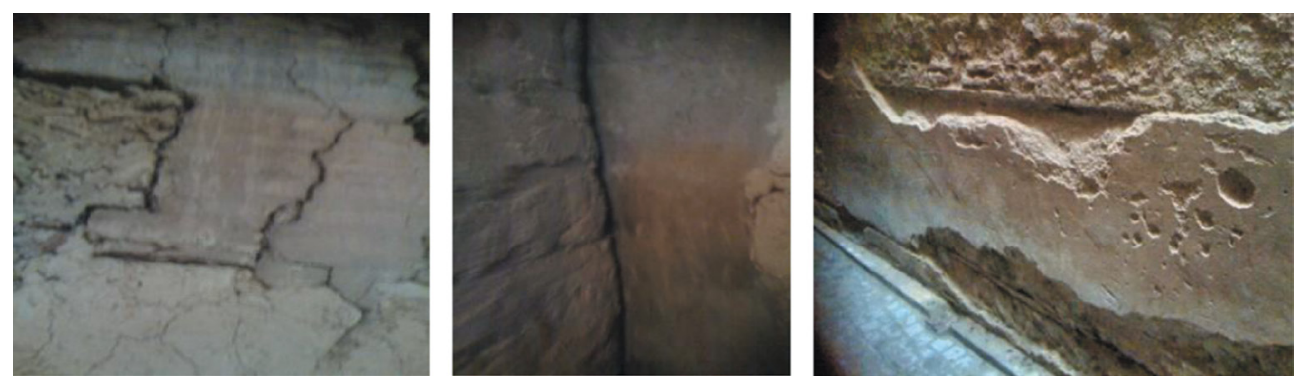

Figure 2: Cracking in walls.
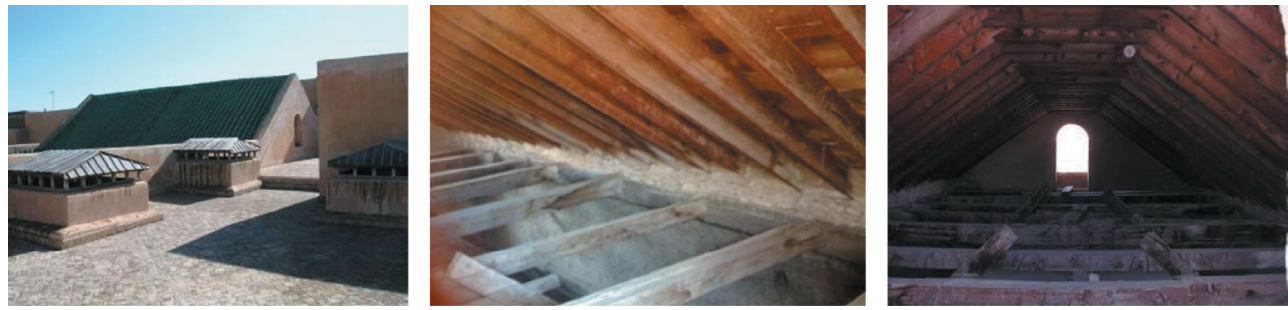

Figure 3: Wooden roof structure.

Table 1: Experimental results of compression strength and modulus of elasticity.

\begin{tabular}{lccc}
\hline & $E(\mathrm{MPa})$ & $R_{\mathrm{c}}(\mathrm{MPa})$ & $\varepsilon_{\lim }(\%)$ \\
\hline Fired clay brick & $1,355.7$ & 7.73 & 0.63 \\
Mortar with 33\% lime & 89.0 & 0.50 & 0.58 \\
Wall & 479.3 & 7.10 & 1.78 \\
\hline
\end{tabular}




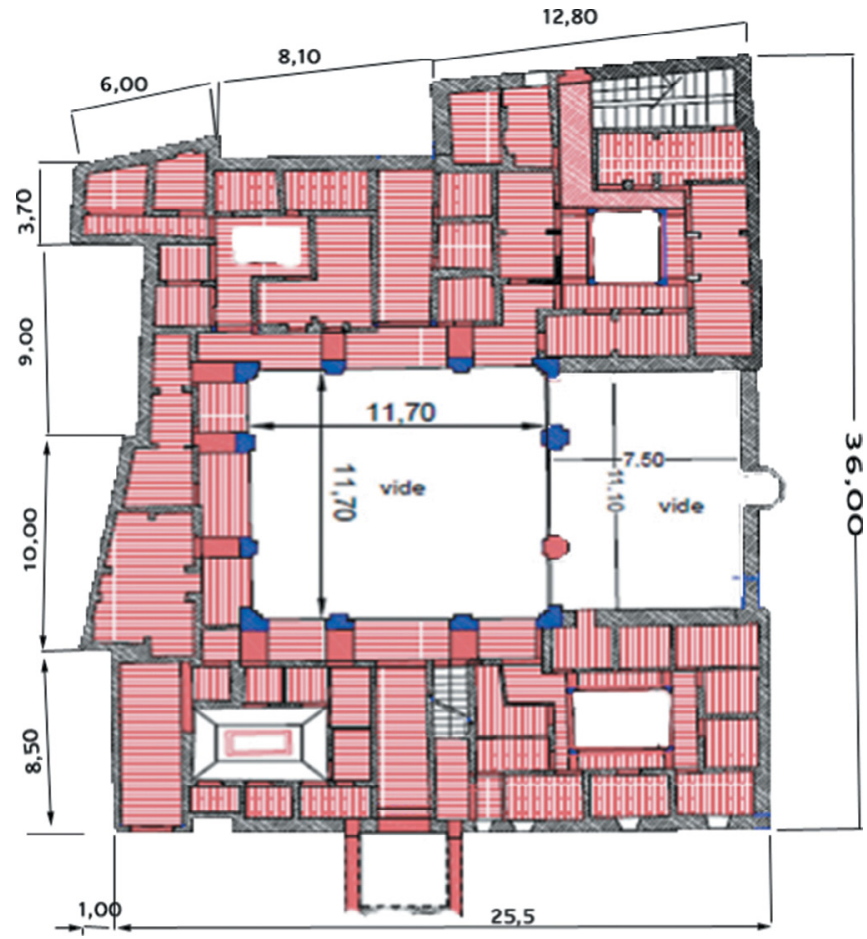

Figure 4: Structural plan of the ground floor.

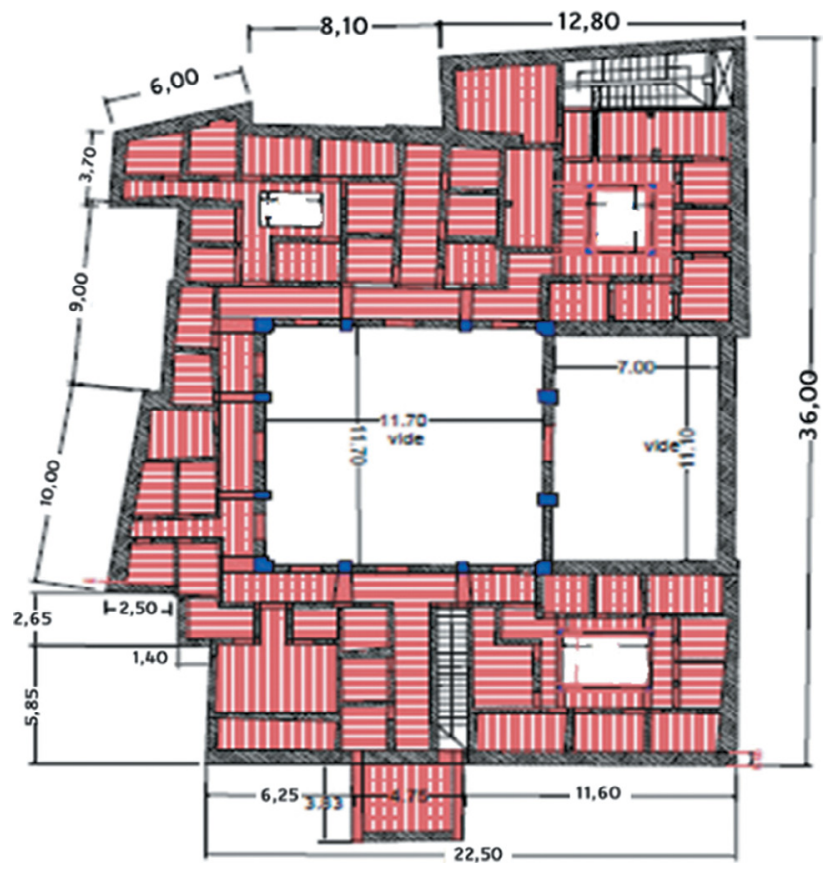

Figure 5: Structural plan of the second floor. 
$\left(10,567 \mathrm{~N} / \mathrm{mm}^{2}\right)$. The beams are embedded in the mass of the wall on which the joists are placed very close and are the most visible part of the floor. This structural system is covered by wooden planks on which is spread a layer of earth well tamped to $40 \mathrm{~cm}$ called Markouz and a final floor covering.

\subsection{Experimental modal analysis}

The test works that have been carried out in Ras Cherratine Madrasa by NIKER partners, UPC team (Polytechnic University of Catalonia, Spain) and ENA team (Ecole Nationale d'Architecture, Morocco), are based on a series of ambient vibration tests using piezoelectric accelerometers. The vibrations have been measured in some places on the roof and at the interior of the second floor. Two kinds of experiments have been carried out in each direction. For the first type, two biaxial accelerometers were used (each including two uniaxial accelerometers placed on a cube block) in different locations. One is fixed and the other is moved to different locations. These experiments allowed to obtain information on the frequencies and modal shapes (mostly the direction and phases of the movements at different points).

The second type of experiments allowed to measure global bending and torsion frequencies and is done by locating a uniaxial sensor in the roof and also in each floor. Although some frequencies are common generally, only the first two modes can be identified as global modes with confidence. These two frequencies are approximately 4 and $10 \mathrm{~Hz}$. It has been confirmed that the first modal displacement occurs in the horizontal direction ( $x$-direction) along with torsional action, whereas the second mode corresponds to transversal displacement (y-direction).

\subsection{Results of seismic performance derived from vulnerability analysis}

Nonlinear static pushover analysis was used on the global model of the Ras Cherratine Madrasa when subjected to a seismic load proportional to mass in the $x$-direction and $y$ direction. The lateral force corresponding to the entire Madrasa is derived from that calculated for the walls in proportion to a coefficient depending on the connection type between the walls (El Azreq et al. [4]). The capacity curves of each wall in both directions of the $x$-axis and $y$-axis (Figs. 6 and 7) are obtained with the following frequencies: $2 \mathrm{~Hz}$ for $x$-direction and $1.8 \mathrm{~Hz}$ for $y$-direction.

Regarding the building performance evaluation, the spectrum capacity and the response spectrum of the ground were used to determine the point of performance. For buildings constructed on a soil of a steep way, and taking a depreciation equal to $1.75 \%$ (El Azreq et al. [5]), the elastic response spectrum acceleration which describes the behaviour of the structure according to its period of vibration can be deducted from RPS2011 (MHUAE [6]), the Moroccan seismic design code that determines the influence of the parameter of acceleration through the amplification factor.

The performance point reflects the allowed maximum displacement of the structure; it represents the point for which the structure and the ground vibrate at the same frequency. For both directions, the real displacements of the Madrasa as a result of an earthquake of $10 \% \mathrm{~g}$ are under the point of performance that defines the limit state of deformation of the structure. The risk of minor to moderate damage is identical in both directions. However, the probability of severe damage or destruction is much higher in the $x$-direction compared with the $y$-direction. 


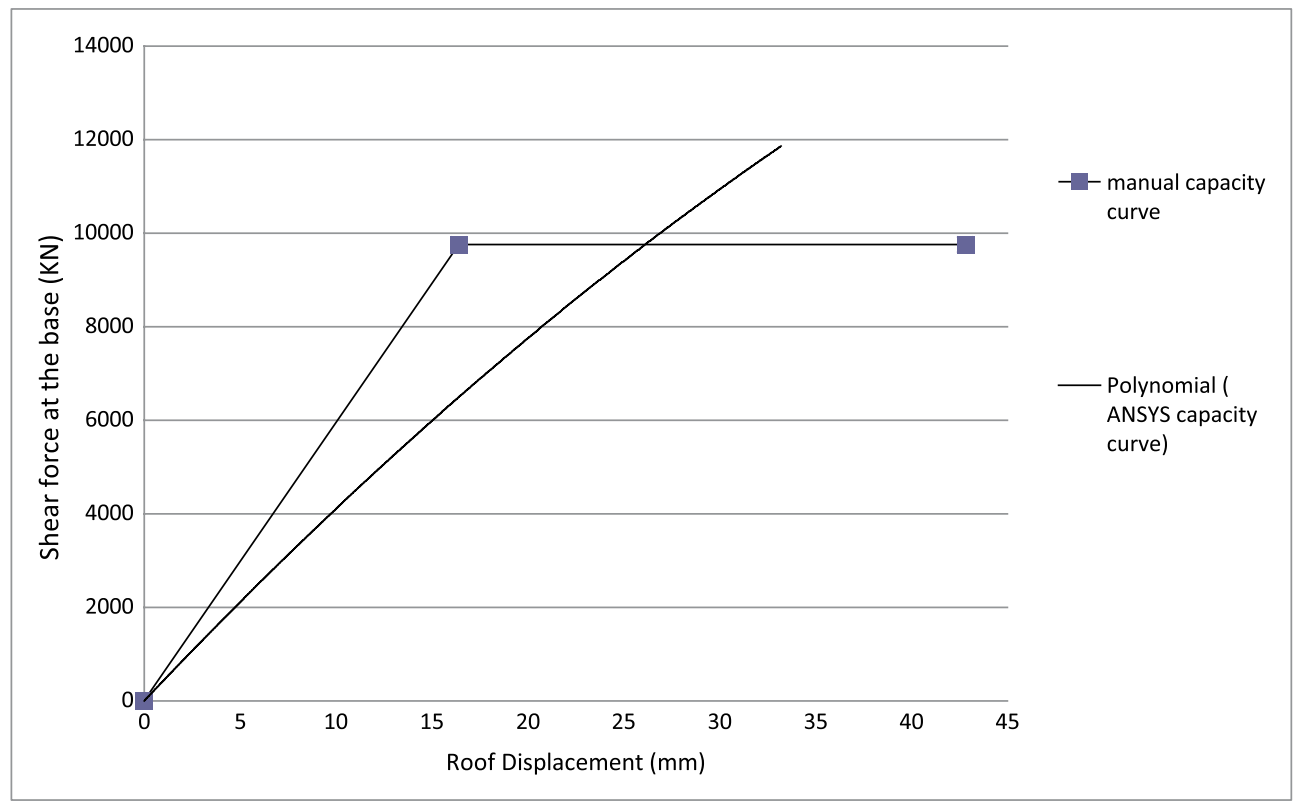

Figure 6: Capacity curves along $x$-direction.

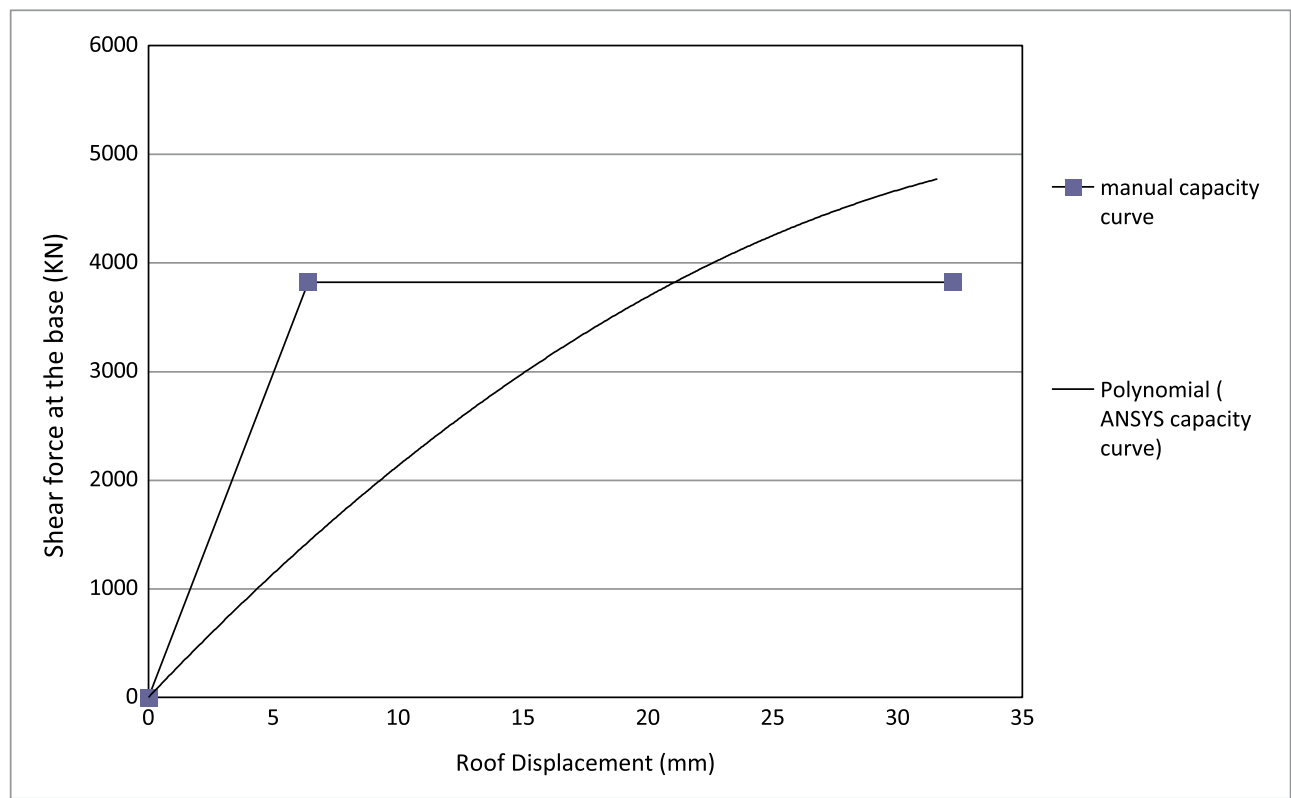

Figure 7: Capacity curves along $y$-direction. 


\subsection{Results of seismic performance derived from structural analysis}

The performed three-dimensional modelling technique is based on the numerical calculations using ANSYS software (Fig. 8): the nonlinear static analysis and the nonlinear modal analysis. The main results obtained by the nonlinear static analysis approach for each seismic acceleration $(\% \mathrm{~g})$ include the deformation $(\%)$, the shear stress (MPa) and the maximum displacements $(\mathrm{cm})$ along $x$ - and $y$-axes. The nonlinear modal analysis allowed to obtain the displacements $(\mathrm{cm})$ along the $x$ - and $y$-axes as the main results for each frequency value.

The structure capacity curves calculated analytically are then compared with those obtained by the nonlinear calculation software. The results are given in Table 2 . The values of the displacements as a function of the ground acceleration obtained by both analytical (the equivalent static method, called the method of spectrum capacity) and numerical modelling (the nonlinear static analysis method) techniques are comparable.

\subsection{Intervention proposal}

Stabilization and urgent measures have not been identified. However, some intervention measures need to be taken in order to overcome the damages and the disorders. These measures are to increase the lateral load resisting forces, so as to form a closed box action between the perimeter walls and allow them to act as monolithic walls to increase their resistance at the global level, and finally to strength the weak locations in the walls.
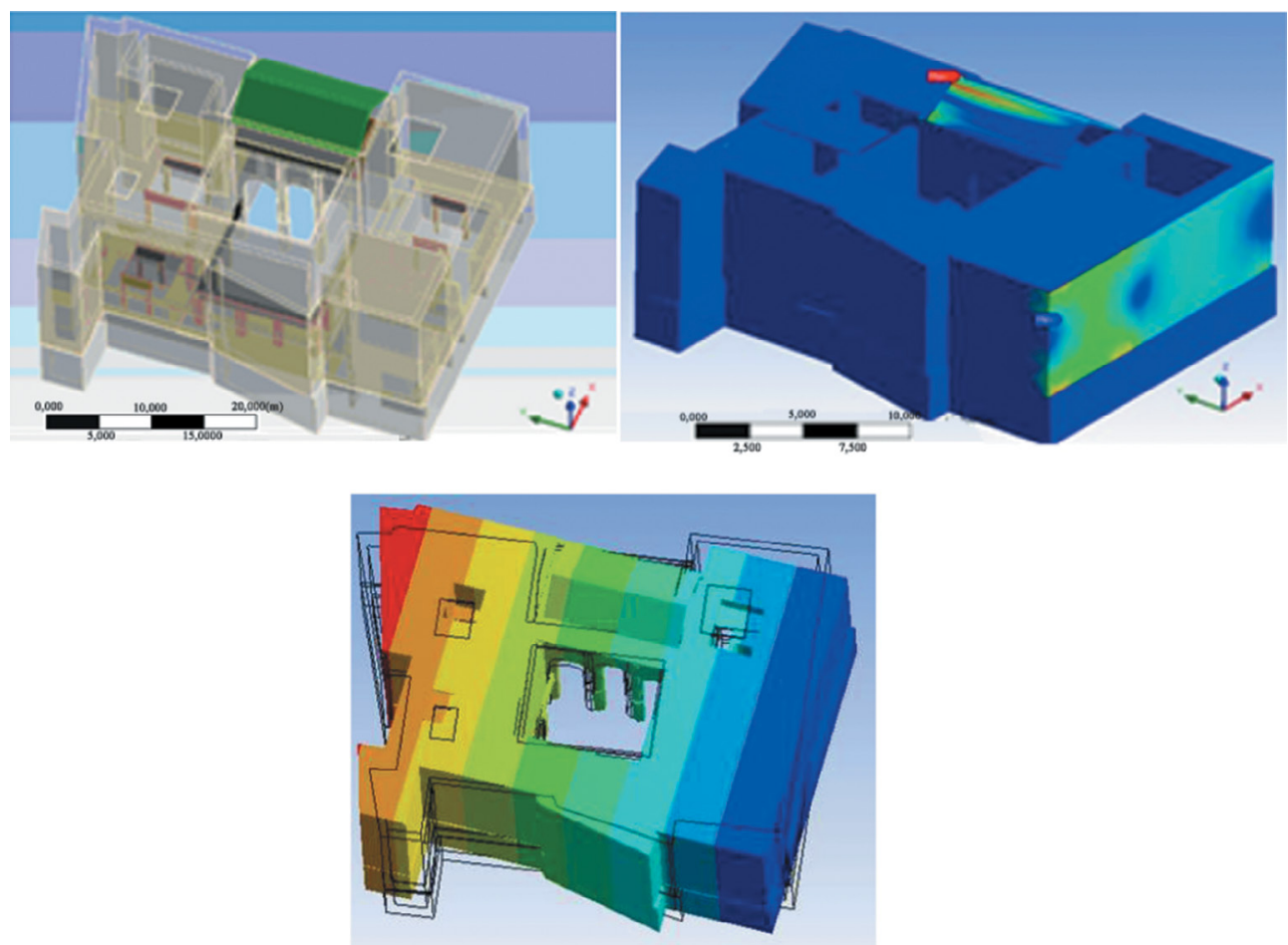

Figure 8: The virtual model of the Madrasa and the nonlinear static and modal analyses. 
Table 2: Resume and results comparison.

\begin{tabular}{|c|c|c|c|c|c|c|c|}
\hline & \multicolumn{3}{|c|}{$\begin{array}{l}\text { Displacement along } x \text { - } \\
\text { axis }(\mathrm{cm})\end{array}$} & \multicolumn{3}{|c|}{$\begin{array}{l}\text { Displacement along } y \text {-axis } \\
(\mathrm{cm})\end{array}$} & \multirow[t]{2}{*}{$\begin{array}{l}\text { Frequency } \\
(\mathrm{Hz})\end{array}$} \\
\hline & $6 \% \mathrm{~g}$ & $10 \% \mathrm{~g}$ & $18 \% \mathrm{~g}$ & $6 \% \mathrm{~g}$ & $10 \% \mathrm{~g}$ & $18 \% \mathrm{~g}$ & \\
\hline Analytical & 2.21 & 2.73 & 3.41 & 2.22 & 2.74 & 3.42 & 2 \\
\hline $\begin{array}{l}\text { Numerical } \\
\text { (nonlinear static } \\
\text { analysis) }\end{array}$ & 2.28 & 2.33 & 3.16 & 2.09 & 2.10 & 2.56 & - \\
\hline $\begin{array}{l}\text { Numerical } \\
\text { (modal analysis) }\end{array}$ & & 1.78 & & & 1.57 & & 4 \\
\hline
\end{tabular}

\subsubsection{Strengthening}

1. The need to increase the seismic capacity in the $x$-direction, discussed previously, requires a more efficient structural connection and connection between the adjoining buildings and the Madrasa.

2. The trend towards a general deformation (a general opening or increase of the spans), in both the $x$ - and $y$-directions, can be controlled by means of some light strengthening, such as a system of light ties, implemented in both directions. In particular, the reinforcing of the openings and the realization of wooden chaining to link the isolated piers should be carried out.

\subsubsection{Repair}

1. Existing cracks in walls should be repaired by means of deep injection or grouting, with possible local reconstruction of the masonry or local substitution of deteriorated fired clay bricks. This action is oriented to ascertain some level of energy dissipation to the building during the occurrence of an earthquake. This energy dissipation would be provided by the generating new cracks in places with limited structural compromise.

2. Most of the deteriorations such as loss of mortar visible in the exterior walls, outside the Madrasa, do not allow a repair based on grout or injection. They can be repaired by means of grout and lime mortar. Walls should also be reinforced with horizontal wooden planks.

\section{CONCLUSION}

Damage analysis related to the ground acceleration of $10 \% \mathrm{~g}$ for the region of Fez Medina has shown that the terrace floor of Ras Cherratine Madrasa building may collapse.

The Madrasa structure reached the performance point and may suffer major damage for seismic accelerations higher than $18 \% \mathrm{~g}$. Analysis of the Madrasa structure with seismic excitation applied to the two horizontal directions of the structure $(x$ and $y)$ has indicated that the Madrasa is vulnerable in both directions. This vulnerability can be justified as follows: The structural system consists of load bearing walls to resist both gravity and lateral loads; there is no connection between the diaphragm and the walls; the flexible diaphragm is unable 
to transfer the shear wall; there is a good system for lateral forces in plane, but it is weak against lateral loads out of plane.

\section{REFERENCES}

[1] Groupe Al Omrane, Médina de Fès, Réhabilitation du Triangle Historique. Groupe Al Omrane: Rabat, 2009.

[2] NIKER, New Integrated Knowledge based approaches to the protection of cultural heritage from Earthquake-induced Risk, 2013, available at www.niker.eu/.

[3] El Alaoui, M.D., La Madrasa Cherratine, Etude historique, architecturale et essai de restauration, INSAP: Rabat, 1996.

[4] El Azreq, M.A., El Hammoumi, A., Iben Brahim, A., El Mouraouah, A., Kerroum, M., Gueraoui, M., Kasmi, M., Birouk, A. \& El Harrouni, K., Analysis of traditional floors and semi-rigidity of walls to floors connections. International Review of Civil Engineering, 2(1), pp. 22-34, 2011.

[5] El Azreq, M.A., El Hammoumi, A., Iben Brahim, A., El Mouraouah, A., Kerroum, M., Gueraoui, M., Kasmi, M. \& Birouk, A., Spectrum response of earthen buildings. International Review of Civil Engineering, 1(4), pp. 266-274, 2010. DOI: 10.4049/jimmunol.0901654

[6] MHUAE, Ministère de l'Habitat, de l'Urbanisme et de l'Aménagement de l'Espace, Règlement de construction parasismique RPS2011 (applicable aux bâtiments), MHUAE: Rabat, 2011. 